\title{
Virus-Host Coevolution with a Focus on Animal and Human DNA Viruses
}

\author{
Győző L. Kaján ${ }^{1}$ (1) · Andor Doszpoly ${ }^{1} \cdot$ Zoltán László Tarján $^{1} \cdot$ Márton Z. Vidovszky ${ }^{1}$ Tibor Papp ${ }^{1}$
}

Received: 6 May 2019 / Accepted: 23 September 2019 / Published online: 10 October 2019

(c) The Author(s) 2019

\begin{abstract}
Viruses have been infecting their host cells since the dawn of life, and this extremely long-term coevolution gave rise to some surprising consequences for the entire tree of life. It is hypothesised that viruses might have contributed to the formation of the first cellular life form, or that even the eukaryotic cell nucleus originates from an infection by a coated virus. The continuous struggle between viruses and their hosts to maintain at least a constant fitness level led to the development of an unceasing arms race, where weapons are often shuttled between the participants. In this literature review we try to give a short insight into some general consequences or traits of virus-host coevolution, and after this we zoom in to the viral clades of adenoviruses, herpesviruses, nucleo-cytoplasmic large DNA viruses, polyomaviruses and, finally, circoviruses.
\end{abstract}

Keywords Virus $\cdot$ Coevolution $\cdot$ Antiviral defence $\cdot$ Endogenous viral elements

\section{Coevolution in General}

Viruses are obligatory cellular parasites, developing with their hosts since the dawn of life. Coevolution, when the virus and the host reciprocally affect each other's evolution, is often detected. According to the Red Queen Hypothesis, both the parasite and the host are perpetually struggling to maintain a constant fitness level (McLaughlin and Malik 2017). This long-term evolutionary pressure gave rise to some surprising consequences for the entire tree of life.

\section{The Origin of Viruses-Which Came First: The Chicken or the Egg?}

What can be the origin of an obligatory cellular parasite? Three concurring hypotheses describe the origin of viruses: (i) the primordial virus world or the virus first hypothesis

Handling editor: Konstantinos Voskarides.

Győző L. Kaján

kajan.gyozo@agrar.mta.hu

1 Institute for Veterinary Medical Research, Centre for Agricultural Research, Hungarian Academy of Sciences, Hungária krt. 21, Budapest 1143, Hungary claims that the ancestors of viruses existed already in the pre-cellular world; (ii) the escaped genes theory describes viruses as mobile genetic elements, which became independent of their host cells; (iii) whereas according to the cellular regression theory, viruses are regressed intracellular parasites (Holmes 2013).

\section{The Primordial Virus World}

According to the primordial virus world hypothesis, in the primordial soup multiple pre-cellular and pre-viral Urorganisms competed with each other. The last universal common ancestor-the first cellular life form-emerged from these primordial replicators, and at least a fraction of current viruses might originate from the remaining ones (Moelling and Broecker 2019). Ancient viruses might have even contributed to the formation of the last universal common ancestor of all living organisms.

It is generally accepted that an RNA-based world preceded today's DNA- and protein-based one. RNA viruses and especially the capsidless viroids might resemble this ancient world (Elena et al. 1991). However, the evolution of viruses-which has been especially rapid for RNA viruses-destroyed the possible signal of genetic relatedness a long time ago, making phylogenetic reconstruction already impossible. Luckily, some sort of evidence is still 
within reach: the existence of viral protein fold superfamilies without cellular counterparts. Proteins without any primary sequence homology are still grouped based on their conserved tertiary structure, their folding: e.g. the major capsid proteins of the PRD1 bacteriophage, adenoviruses and some archaeal viruses all have a double jellyroll fold structure (Benson et al. 1999; Nasir and CaetanoAnollés 2015, 2017), or there are structural homologies in the RNA- and DNA-dependent polymerases too (Gorbalenya et al. 2002). There are fold superfamilies containing both viral and cellular proteins (we will return to this phenomenon by the escaped genes theory), but there are also numerous examples without cellular homologues found in phylogenetically very diverse viruses: e.g. viral RNA-dependent RNA polymerases are not homologous to their cellular counterparts (Iyer et al. 2003). According to the most parsimonious assumption, these proteins have a common origin in the primordial virus world, and phylogenetic tree reconstructions of these fold superfamilies confirm this as well (Nasir and Caetano-Anollés 2015).

Viruses became obligatory parasites either only after the emergence of the last universal common ancestor, or it is equally possible that they were already parasitizing on other ancient replicators. According to the viral eukaryogenesis hypothesis, even the eukaryotic cell nucleus originates from an infection by a coated virus: the virus became an endosymbiont usurping the role of the original archaean nucleus (Bell 2009). The endosymbiont pox-like virus had no possibility for a lytic viral cycle, and under this evolutionary pressure started to replicate by means of cell-to-cell fusion using its fusion proteins. When two such cells-infected by related viruses-fused to each other, the viral DNA was copied, and homologous viral chromosomes formed tetrads. Cell division resulted in four daughter cells with one copy of the endosymbiont virus in each. This might be the origin of meiotic cell division (Bell 2006). After its development, sexual reproduction offered a significant fitness advantage in the fight against any parasite (Hamilton et al. 1990), including viruses.

\section{Escaped Genes}

This theory states that mobile genetic elements escaped the cell, acquired a protein capsid and started to replicate autonomously (Moreira and López-García 2005, 2009). Numerous homologies can be observed among viral and cellular genes. On the other hand, the root position, and thus the certain direction of evolution, might be challenging to determine. For example, cellular and viral DNA polymerases are related (Filée et al. 2002), but the exact direction of the lateral gene transfer is unknown (Shackelton and Holmes 2004).

\section{The Cellular Regression Theory}

Perhaps the least favoured theory currently claims that viruses are the extremely reduced descendants of obligatory intracellular parasites, incapable of autonomous extracellular life (Bândea 1983). According to this theory, the viral genome is the remnant of a heavily reduced cellular genome and the capsid is that of a cell membrane. The nucleo-cytoplasmic large DNA viruses (NCLDVs) are good candidates to represent the end result of this mechanism: they proliferate in the cytoplasm, and have particle and genome sizes comparable to those of the smallest prokaryotes (Arslan et al. 2011; Colson et al. 2012, 2011). The modern version of this theory was mentioned when discussing the primordial virus world: viruses might be the reduced descendants of pre-cellular Ur-organisms, converting into obligatory cellular parasites (Claverie 2006; Forterre 1991).

\section{Viral Genetic Elements in Host Genomes}

\section{Polintons}

The theories of viral origin are a topic of heated debate, but most possibly none of them is mutually exclusive, and the suspected processes of two or more could have occurred parallel and/or sequentially as well. A small proportion of mobile genetic elements might have its root in the primordial virus world, but numerous regression or escape occasions must have occurred too. The latter were perhaps facilitated by the cellular genomic insertion of viral genetic elements. Polintons, also known as Mavericks, are mobile genetic elements with multiple homologues in both cellular and viral genomes. They have escaped several times and gave rise to different viruses and mobile genetic elements such as adenoviruses or mitochondrial linear plasmids (Krupovic and Koonin 2015, 2017). It must be stressed again that these genetic elements are homologous and related, but the direction of the genetic exchange is unknown in most cases. Such transfers are common from host to virus and vice versa too.

\section{Endogenous Viral Elements}

Endogenous viral elements (EVEs) are viral genes or sometimes complete genomes inserted into host genomes. As genome integration is a compulsory step in retroviral replication, most of these elements are of retroviral origin, but further virus families were detected as well: hepadnaviruses, adeno-associated viruses, herpesviruses and others (Aiewsakun and Katzourakis 2015; Bill and Summers 2004; Broecker and Moelling 2019; Morissette and Flamand 
2010; Young and Samulski 2001). If the insertion occurs in the germ cell line, the inserted sequence stretch might get inherited. And if it provides a selective advantage, e.g. protection from a viral infection, the genomic change will be fixed in the population. In case this advantage disappears, the inserted stretch might mutate over time and lose its protective nature (Broecker et al. 2016).

EVEs are important sources for virus-host coevolutionary research, as they provide a map for viral host range. The history of coevolution can be traced by the detection of homologous endogenous viral sequences in different host species. This provides information about the historical host range of a virus clade, and even the time frame of coevolution can be inferred based on the known diversification times of the hosts, or on phylogenetic analyses of exo- and endogenous viral sequences. E.g. based on endogenous lentiviral sequences in lemurs, it was hypothesised that these viruses have been coevolving with primates for several millions of years (Katzourakis et al. 2007).

Viruses represent a major force in evolutionary pressure (Emerman and Malik 2010; Villarreal and Witzany 2010). Retroviruses, for example, are so effective in genome integration and have been coevolving with vertebrates so long, that over $50 \%$ of the human genome was estimated to consist of endogenous retroviral elements (de Koning et al. 2011). Some of these regions provide important and fundamental attributes to their integrator hosts, like the syncytin genes, which have an important role in placental development not only in various mammals but in viviparous lizards as well (Cornelis et al. 2017; Imakawa and Nakagawa 2017). Other transposable elements contribute to embryonic development, stem cell pluripotency or cell differentiation in eukaryotes (Chuong et al. 2017). In prokaryotes, important functions were attributed to the integrated viruses as well. E.g. in $E$. coli, deleting all prophages has resulted in increased susceptibility to environmental factors and slower cell growth (Wang et al. 2010).

\section{Effects of the Bottleneck Phenomenon}

Essentially, the viral mutation rate and copy number determine the variability within the host and in fine the stock of viral evolution (Duffy et al. 2008; Peck and Lauring 2018; Sanjuán and Domingo-Calap 2016). Generally, viral pathogens exist in diverse populations in vivo (McCrone and Lauring 2018). As a substantial evolutionary effect on the population dynamics of viruses, genetic bottleneck (reduction of effective population size due to environmental events, for instance new habitat colonisation) affects the virus-host coevolution: it decreases both the genetic variation and the fitness of the virus, and furthermore it is responsible for the founder effect (Novella et al. 1995). Changes of genotype frequencies by stochastic population size reduction are referred to as genetic drift (Bergstrom et al. 1999; Dennehy et al. 2006; Elena et al. 2001; McCrone and Lauring 2018; Zwart and Elena 2015). Furthermore, it is important to stress that the phenomenon of genetic bottleneck is interpretable from both virus and host perspective (Voskarides et al. 2018).

In the case of the viruses, the newly colonised region might be a new host (host switch) or organ (Voskarides et al. 2018; Zwart and Elena 2015). Bottleneck events occur during both intra- and inter-species steps of the viral life cycle (Gutiérrez et al. 2012). An interesting aspect of virus evolution and the bottleneck effect is the case of multipartite viruses (e.g. plant-infecting nanoviruses or animal-infecting bidnaviruses, alphatetraviruses, nodaviruses and picobirnaviruses). These package their genetic material as independently encapsidated separate segments (Lucía-Sanz and Manrubia 2017). Self-evidently, bottleneck events have a crucial role for these viruses, as all genomic segments are needed for a successful infection. Furthermore, the different genomic segments drift at different rates (Gallet et al. 2018).

\section{Antiviral Defence Mechanisms}

Under the constant threat of an infection, cellular organisms have developed multiple layers of different defence mechanisms (not solely) against these genetic parasites to protect themselves and their genomic integrity.

\section{Shuttled Weapons}

Most strikingly, antiviral defence mechanisms often have viral origins too (Broecker and Moelling 2019; tenOever 2016; Villarreal 2009). The simplest mechanism is the superinfection exclusion, where an integrated and expressed endogenous viral protein provides protection from exogenous infection. This was first described in the tobacco plant, but it is applied by prokaryotes, animals or other plants as well (Moelling et al. 2017). The development of such a defence mechanism was observed in sheep and koalas for example. Retroviral elements were endogenised even as recently as 200 and 100 years ago in the genomes of sheep and koala, respectively, providing protection against certain exogenous retroviral infections (Armezzani et al. 2014; Tarlinton et al. 2006).

But such basic integrations are not the only examples. The recently described bacterial antiphage system, CRISPRCas (Charpentier and Doudna 2013), has its roots in at least five different classes of mobile genetic elements (Koonin and Makarova 2017). The Argonaute proteins show structural and functional homologies to the retroviral replication machinery and provide protection against invading nucleic 
acids in prokaryotes (Moelling et al. 2006). The RNA interference system of eukaryotes shares the same homologies, and it is available in each of the five eukaryotic superkingdoms, suggesting a very ancient evolutionary origin (Cerutti and Casas-Mollano 2006). Though present, this system does not provide antiviral effects in chordates. But also here, endogenous retroviruses provide transcription factor binding sites for interferon-stimulated genes (Chuong et al. 2016; Ito et al. 2017), whereas the Rag recombinases-needed for the diversification of antibodies - originate from transposons found in the genomes of starfish, oysters and sea urchins (Kapitonov and Koonin 2015).

\section{Other Mechanisms}

The most ancient defence mechanism might be the use of antisense RNAs, where the gene translation of the invading pathogen is interfered by small complementary RNAs (Gottesman and Storz 2011). Against DNA phages, bacteria often use restriction endonucleases, cleaving the viral genome (Kobayashi 2001). Piwi-interacting RNAs associate with nucleases and provide defence against transposable elements. The latter are available in all metazoans, and they may have a common origin with the prokaryotic Argonaute system (Iwasaki et al. 2015). As already mentioned, the RNA interference does not provide an antiviral effect in chordates; instead, pattern recognition receptors were developed. Engagement of these by pathogen-associated molecular patterns (i) induces antiviral cytokines: the tumour necrosis factor, available in most eukaryotic lineages, but in chordates rather the interleukins and interferons (Levy et al. 2011), and (ii) activates the natural killer cells too (Esteso et al. 2017). The APOBEC3 protein is part of the innate immune system in humans, it targets specifically retroviruses and interferes with their reverse transcription (Sheehy et al. 2002). However, HIV counteracts this effect by the viral infectivity factor, which triggers the degradation of APOBEC3 (Donahue et al. 2008). Furthermore, it was also observed that human leucocyte antigen I and II loci are genetically more diversified in pathogen- (most predominantly virus-) rich environments (Prugnolle et al. 2005; Sanchez-Mazas et al. 2012).

After this short general introduction on the highlights of the topic, we focus on the coevolutionary processes of selected DNA viruses: adeno-, herpes-, NCLD-, polyomaand circoviruses.

\section{Adenoviruses}

Adenoviruses are DNA viruses, the major capsid proteins of the non-enveloped, icosahedral capsid are the hexon, the penton base and the protruding fibre, responsible for receptor binding. Their non-segmented, double-stranded, linear genome varies between 26 and $45 \mathrm{kbp}$ in size, and the DNA is covalently bound to the terminal protein (Harrach 2014). Adenoviruses infect vertebrate hosts, and are clustered into five accepted and one proposed genera. Members of the genera Mastadenovirus and Aviadenovirus infect mammals and birds, respectively. Atadenoviruses were detected in reptiles, birds, ruminants and a marsupial possum; siadenoviruses in birds, a frog and a tortoise. The single member of the genus Ichtadenovirus is the white sturgeon adenovirus. The sixth genus was proposed recently: testadenoviruses were detected in testudinoid turtles only until now (Doszpoly et al. 2013).

As these viruses were described from five major classes of the vertebrates, the hypothesis was formed that adenoviruses had started to coevolve with the vertebrates 450 million years ago, before the divergence of fish from other vertebrates (Kovács et al. 2003). Mast-, avi-, at-, si- and ichtadenoviruses had been thought to coevolve with mammals, birds, reptiles, amphibians and fish, respectively (Benkő and Harrach 2003). This hypothesis was partially questioned later, as the white sturgeon and the frog adenovirus - the latter belonging to genus Siadenovirus - are the single fish or amphibian adenoviruses, respectively, discovered until now (Davison et al. 2000; Doszpoly et al. 2019). Furthermore, several avian adenoviruses clustered into the genus Siadenovirus (Ballmann and Harrach 2016; Kovács and Benko 2011; Kovács et al. 2010; Lee et al. 2014). Yet, it is equally possible that several further amphibian and fish adenoviruses are awaiting discovery.

Adenoviruses are generally thought to be host specific with usually one or very few host species for a specific viral serotype. Still, during the hundreds of millions of years, host changes did happen, e.g. there were ten predicted host switches in the evolution of human adenoviruses in 4.5 million years (Hoppe et al. 2015). The most striking assumed host switch happened for some atadenoviruses. These are thought to be the lineage coevolving with squamatid reptiles originally (Wellehan et al. 2004), but presumably a virus strain had jumped to an ancient ruminant during the evolutionary history. Atadenoviruses were isolated from cattle, sheep and mule deer, suggesting some level of coevolution already. However, the high genomic A $+\mathrm{T}$ content-hence the name atadenovirus - contradicts long cospeciation of these viruses (Benkô and Harrach 1998).

Non-reptile atadenovirus genomes are characterised by 57.0-66.3\% A + T content, whereas reptile atadenoviruses are not affected by such bias (Farkas et al. 2002; Harrach 2008; Papp et al. 2009; Wellehan et al. 2004). Examples from other virus families are known: the influenzaviral nucleotide composition changes following a host jump from bird to mammal (Greenbaum et al. 2008), or similar differences were observed between flaviviruses or herpesviruses of different hosts (Jenkins et al. 2001; McGeoch et al. 2006). 
Obviously, this composition has an effect on codon usage, thus the complete genome sequence might be under evolutionary pressure (Shackelton et al. 2006). Still, the exact cause of this bias in atadenoviruses is unknown, but it is hypothesised that longer coevolutionary times-adaptation of the virus to the host-result in a balanced nucleotide composition (Farkas et al. 2002; Papp et al. 2009; Wellehan et al. 2004).

Similar observations were made about pathology. Adenoviruses generally cause a mild disease, and there are apathogenic strains at least in healthy individuals. E.g. recent research shows that only specific and not all serotypes of the species Fowl aviadenovirus $D$ and $E$ cause inclusion body hepatitis in chicken (Schachner et al. 2018; Zadravec et al. 2011). But recent host switches might result in an elevated pathogenicity (Benkő and Harrach 2003; Jánoska et al. 2011; Kohl et al. 2012; Vidovszky et al. 2015). For instance, duck adenovirus 1 is apathogenic in ducks and geese, but causes the egg drop syndrome in chickens (Hess et al. 1997). Another atadenovirus causes a haemorrhagic epizooty among mule deer (Lehmkuhl et al. 2001; Woods et al. 1996). Or bovine adenovirus 10 - though a mastadenovirus - is only distantly related to other bovine mastadenoviruses, and it causes a severe acute fibrinous enterocolitis (Horner et al. 1989). The $\mathrm{A}+\mathrm{T}$ content of the known genome part is over 59\%, and from serologically identical strains several fibre size variants were described (Ursu et al. 2004). These mutations might be the consequences of an ongoing evolution, and represent the adaptation to a relatively new host, cattle (Benkő and Harrach 2003).

The most investigated adenoviruses are evidently human and other primate adenoviruses. Codivergence is not obvious here at the first look as host switches blur the picture (Hoppe et al. 2015; Purkayastha et al. 2005; Roy et al. 2009; Wevers et al. 2011), but it is still observable. The most ancient lineages are the prosimian and New World monkey adenoviruses (Podgorski et al. 2018). On the next branches we can find the Old World monkey adenoviruses including members of Human mastadenovirus (HAdV) $A, F$ and $G$ (Gilson et al. 2016; Pantó et al. 2015; Podgorski et al. 2016) (Fig. 1). Evolutionarily speaking, strains of HAdV-B and -E are of gorilla or chimpanzee origin, respectively; and strains of HAdV-B jumped to the common ancestor of humans and chimpanzees two times most probably (Hoppe et al. 2015). HAdV-C seemingly codiverged with gorillas, chimpanzees, bonobos and humans, whereas HAdV-D viruses infect only humans (Hoppe et al. 2015). The long-term coevolution of HAdV-D and humans is supported by the high variety of types within the species (Ismail et al. 2018b; Kaján et al. 2018), and their usually facultative pathogen nature.

Exactly in HAdV-D strains it is often observed that homologous recombination has a driving force in adenovirus evolution (Crawford-Miksza and Schnurr 1996; Gonzalez et al. 2015; Ismail et al. 2018a; Kaján et al. 2017; Robinson et al. 2013; Walsh et al. 2009). Predominantly, intraspecies recombination events are common, but intergenus recombinants have also been reported already: the head domain of the porcine adenovirus 5 (genus Mastadenovirus) fibre seems to be of atadenoviral origin (Nagy et al. 2002), though a porcine atadenovirus has not been discovered yet. Recombination enables an accelerated, modular evolution of viruses, 'and has been associated with such features as the evasion of host immunity (Malim and Emerman 2001), the development of antiviral resistance (Nora et al. 2007), the ability to infect new hosts (Hon et al. 2008), increases in virulence (Khatchikian et al. 1989) and even the creation of new viruses (Weaver 2006)' (Holmes 2013).

\section{Herpesviruses}

Herpesviruses (HVs) are large (150-200 nm) icosahedral, enveloped viruses having a so-called tegument layer between the capsid and the envelope. HVs possess a linear, nonsegmented, double-stranded DNA genome (135-295 kbp) (Pellett et al. 2011). They are known to infect all classes of vertebrates, from fish to humans; moreover, HVs were discovered in some mollusc species as well (Davison et al. 2009). Chronologically, HVs of mammals and birds were known first causing different diseases in humans, livestock and poultry. Later, several decades ago, HVs of reptiles, fishes and amphibians were also reported (Fawcett 1956; Rebell et al. 1975; Wolf and Darlington 1971). These novel viruses were tentatively classified into the family Herpesviridae because of their morphological features. The first nonvertebrate $\mathrm{HV}$ was discovered in a mollusc species in the 1970s (Farley et al. 1972). As more sequence data became available, molecular analysis provided insight into the evolution of HVs, and these newly discovered viruses were also officially classified into the family Herpesviridae (Davison 1998; Davison et al. 2006, 2005; Davison and Davison 1995; McGeoch and Gatherer 2005). In 2009, the taxonomy of HVs changed radically, as the family Herpesviridae was split into three families. The novel family Herpesviridae contains only the HVs of higher vertebrates (Amniotes), while the family Alloherpesviridae contains the HVs of amphibians and fish (Anamnia), and the family Malacoherpesviridae contains the HVs of molluscs. The three families were clustered under the novel order Herpesvirales (Davison et al. 2009). These three groups of HVs are related only tenuously to each other. There are only a few genes showing homology in all known HVs, the most conserved gene is the putative ATPase subunit of terminase, its gene product being responsible for the packaging of the viral DNA into the capsid (Davison et al. 2009). Interestingly, a homologous gene was found in T4 bacteriophages (Myoviridae) implying 


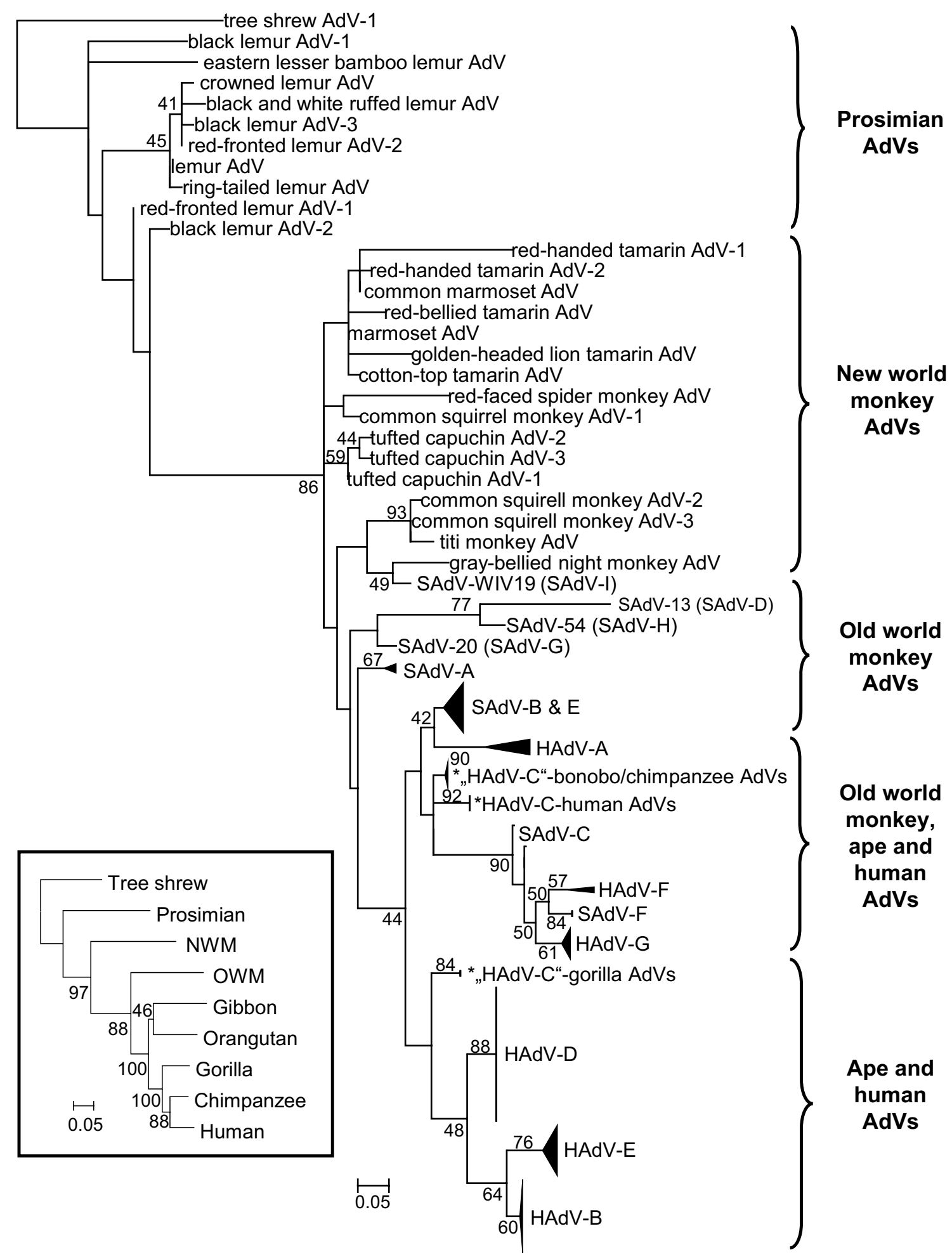

Fig. 1 Phylogeny reconstruction (maximum likelihood analysis) based on partial sequences of the IVa2 protein of primate adenoviruses (AdVs). A phylogenetic tree of primates is shown in the bottom left corner to demonstrate the parallel evolution of AdVs and hosts. SAdV-A, Simian mastadenovirus A; HAdV-B, Human mastadenovi- rus B, etc. Hosts of AdVs presumably belonging to species HAdV$\mathrm{C}$ are marked with asterisks due to their separation. [From Podgorski et al.: Adenoviruses of the most ancient primate lineages support the theory on virus-host coevolution (2018) Acta Vet Hung 66:474, with permission from Akadémiai Kiadó.] 
the common origin of $\mathrm{HVs}$ and tailed bacteriophages (Baker et al. 2005).

The phylogenetic relationship of HVs is well studied and their evolution was found to be largely synchronous with host lineages (McGeoch et al. 2000, 2006). Exceptions have been noted among the mammalian (McGeoch et al. 2006) and fish HVs (Kelley et al. 2005). The major sublineages within the subfamilies (Alpha-, Beta-, Gammaherpesvirinae) of Herpesviridae emerged probably before the mammalian radiation, 60 to 80 million years ago, while the diversification time point of the three subfamilies had been around 200 million years ago (McGeoch et al. 1995, 2000). The most common ancestor of all known HVs (order Herpesvirales) existed around 400 million years ago based on similar phylogenetic branching patterns of HVs and host lineages (McGeoch et al. 2006).

As for mammalian HVs, several studies were conducted on their evolutionary route spanning shorter time periods. For example, Bovine herpesvirus 4 (BoHV-4) has been isolated from cattle worldwide and this species was thought to be the original host of the virus. However, BoHV-4 has been reported from wild buffalo and other ruminants as well (Rossiter et al. 1989; Todd and Storz 1983). Later, serological studies implied that the original host of the virus might be the African buffalo (Syncerus caffer) (Dewals et al. 2005). This hypothesis was confirmed by phylogenetic calculations, suggesting that BoHV-4 has been coevolving with the African buffalo for the last 1.5 million years, and the virus was passed to cattle on at least three independent occasions much more recently, sometimes via an intermediate species (Dewals et al. 2006). In another study, the phylogenetic trees of primate cytomegaloviruses and their hosts' were compared, and primate cytomegalovirus genomes were also analysed. The obtained results demonstrated the coevolution of these viruses with their hosts (Russell et al. 2016). Furthermore, the avian and reptilian HVs were clustered into the subfamily Alphaherpesvirinae, relating to the development of birds from reptilian progenitors (McGeoch and Gatherer 2005).

As for the members of the family Alloherpesviridae, phylogenetic inferences strongly support the monophyly of fish and amphibian HVs within the order Herpesvirales (Waltzek et al. 2009). The comparison of the phylogenetic trees of viruses and hosts implied that closely related HVs in the family may have coevolved with their hosts, whereas codiversification was not supported at deeper nodes of the tree (Waltzek et al. 2009). In other words, the separation of the main alloherpesvirus lineages does not fully resemble that of the host taxa. One explanation can be that the ancestors of the different viruses diverged before the separation of the various fish lineages, and thus the different virus lineages evolved independently. The strong similarity among viruses of distantly related fish species could be explained by host switches (Doszpoly et al. 2011).
Integrated herpesviral genomes in host chromosomes were also discovered in the last years, giving insight into the virus-host coevolution and providing interesting data about the genome organisation and content of ancient virus species (Aswad and Katzourakis 2017; Inoue et al. 2017; Savin et al. 2010). The discovery of a new lineage of alloherpesviruses associated with at least fifteen different fish species was reported. One of them seems to represent a full-length viral genome in salmon (Salmo salar) (Aswad and Katzourakis 2017). An interesting discovery of a HV genome integrated into the genome of an invertebrate chordate provides links to the ancient ancestors of mollusc and vertebrate HVs: the genome of Branchiostoma floridae (Florida lancelet or amphioxus) contains several genes showing homology to herpesviral genes, implying the existence of a HV associated with this invertebrate chordate. The terminase and polymerase gene sequences from the putative amphioxus HV show higher similarity to those of the mollusc HVs than to any vertebrate HVs (Savin et al. 2010). The discovery of this virus gave data about HVs dating back to the separation of vertebrates and invertebrates.

\section{Nucleo-cytoplasmic Large DNA Viruses}

Nucleo-cytoplasmic large DNA viruses (NCLDV) are a group of DNA viruses including the families Ascoviridae, Asfarviridae, Iridoviridae, Marseilleviridae, Mimiviridae, Pithoviridae, Phycodnaviridae and Poxviridae (Koonin and Yutin 2010, 2019). A new virus order, the Megavirales was proposed [but not yet accepted by the International Committee on Taxonomy of Viruses (ICTV)] to collect the abovementioned virus families (Colson et al. 2013). Their host range spans from unicellular eukaryotes via arthropods to vertebrates (even mammals). NCLDVs replicate within the cytoplasm of the infected cells, yet in some families (e.g. iridoviruses) a nuclear stage is also present. Hence, NCLDVs encode many genes required for their own successful replication, but still use the translational apparatus of the host. Although the genome size (between 100 and $2500 \mathrm{~kb}$ ) and host range of NCLDVs vary greatly, they appeared to form a monophyletic group with a common ancestor, based on a subset of about 30 conserved genes (Filée et al. 2008). For instance, iridoviral homologues of ATPase, the A1L/VLTF2 transcription factor, the major capsid protein and the DNA polymerase proteins show considerable sequence similarity with asfar-, asco-, mimi-, pycodna- and poxvirus counterparts (Boyer et al. 2009).

In 2003, the discovery of mimivirus, the first giant amoeba virus (La Scola et al. 2003) with its large virion $(700 \mathrm{~nm})$ in the size range of bacteria and archaea, altered a century-long vision about the sizes and genome structures in the virosphere. Its genome was also huge 
(1200 kb) (Raoult et al. 2004), comparable to the smallest free-living prokaryote genomes (Koonin 2009), and contained several genes of distant origins (eukaryotic, bacterial or viral) acquired by lateral/horizontal gene transfer (Filée 2009). This led to the concept of 'giant viruses are giant chimeras' (Moreira and Brochier-Armanet 2008). The mimivirus was found to contain nearly all NCLDV core genes and clustered phylogenetically with phycodnaviruses based on these (Claverie et al. 2009, 2006). This suggested that it was an oversized NCLDV. Nonetheless, the translation system component genes seemed to illustrate a divergent evolutionary past. On the corresponding phylogenetic trees, mimiviruses clustered on a distinct branch, separated from the three established domains of cellular life (bacteria, archaea and eukaryotes). This striking novel observation has triggered the 'fourth domain hypothesis', according to which giant viruses evolved from cellular ancestors, most likely of an extinct fourth domain, via the reductive evolution route (Colson et al. 2012, 2011). However, the most recent evolutionary reconstruction favoured a less peculiar alternative hypothesis, the multiple origin of viral gigantism (Koonin and Yutin 2018). This latter analysis, based on well-conserved genes, defined three major branches on the NCLDV tree, suggesting at least three independent emergences from smaller viruses. For the translation-related genes, phylogenetic analysis showed kinship between viral and different eukaryotic lineages, suggesting lateral gene transfers at different time points of the virus evolution. Further evolutionary reconstructions revealed a connection between NCLDVs and smaller eukaryotic viruses, e.g. adenoviruses, and ultimately, derived all these viruses from tailless bacteriophages (Koonin and Yutin 2019). The reconstructed phylogeny was as follows. Branch \#1 included most of the real giants $(>500 \mathrm{~kb})$ : the extended family Mimiviridae and pandoraviruses. Branch \#2 gathered the families Asco-, Irido-, Marseille- and Pithoviridae. This branch contained the widest variation of genome sizes $(100 \mathrm{~kb}$ to $1500 \mathrm{~kb}$ ). Branch \#3 included only non-giants in two distinct clades: Asfarviridae (African swine fever virus and its protist-infecting relatives) and Poxviridae. According to the present knowledge, a major host switch took place two times along this branch. Once during the early history of poxviruses, which infect both arthropods and vertebrates, two animal phyla that radiated from the common ancestor more than 500 million years ago (Oliveira et al. 2017). Thereafter an apparent coevolution with the hosts also took place within the two subfamilies resulting in what we see today: several genera and poxvirus 'types' infecting a wide range of arthropod and vertebrate species. The second host switch happened at a later evolutionary stage in the sensu lato asfarviruses. Within this group a few apparently related viruses infect protists and pigs too
(Alonso et al. 2018; Andreani et al. 2017; Bajrai et al. 2016).

Shifting the perspective to branch \#2 families: we can see that using a concatenated set of 9 genes common to these, a close relationship has been confirmed, suggesting that ascoviruses emerged recently and share a common ancestor with invertebrate iridoviruses (Piégu et al. 2015). However, the replication strategies and morphologies are markedly different in these two virus groups replicating in invertebrate hosts (Federici et al. 2009). The evolutionary steps leading to these significant alterations still remain obscure.

This phylogenetic reconstruction of the NCLDVs demonstrated a 'turbulent evolution', which was dominated by gene gain, while on other branches substantial gene loss was apparent. The branches that include giant (protist) viruses are the most prominent gene gainers, whereas NCLDVs infecting animal hosts have undergone considerable gene losses, a sort of 'genome contraction' during their evolution from ancestral protist viruses. It was hypothesised that in animals, the selective pressure for virus genome size is stronger than in protists, yet its mechanism needs to be analysed (Koonin and Yutin 2018).

\section{Polyomaviruses}

Polyomaviruses (PyVs) are non-enveloped icosahedral DNA tumour viruses with a double-stranded, cca. 5000-bp-long circular DNA genome. Approximately 80 accepted PyV species form the family Polyomaviridae; the species are clustered into four genera (Alpha-, Beta-, Gamma- and Deltapolyomavirus) according to the ICTV. The taxonomical classification of PyVs is based on the genetic distance of the large tumour antigen. Still, some PyVs cannot be categorised into any accepted genus, so these require additional genera in the future (Moens et al. 2017a).

The organisation of the circular PyV genome is highly conserved: the 5-7 genes are located on both strands, and distributed into early and late regions. There is a non-coding control region as well. The early coding region contains regulatory proteins: the small and the large tumour antigen. The late coding region contains the genes of the structural proteins, like the major (VP1) and two minor capsid proteins. The approximately 500-bp-long non-coding control region contains regulatory elements and transcription promoters, the origin of DNA replication (Moens et al. 2017b).

PyVs are known to infect mammals and birds, but using viral metagenomics, PyVs were identified and characterised also in fish and arthropods (Buck et al. 2016; Peretti et al. 2015). Analysing the available divergent sequence data of PyVs, results indicate that PyVs have been progressively coevolving with their hosts for about half billion years. Still, the current taxonomic classification system does not reflect 
this coevolution. This might be explained using phylogenetic analyses of PyV genes: some modern PyV species arose after ancient recombination events involving distantly related PyV lineages (Buck et al. 2016). The mammalian PyVs are known to be highly host specific and coevolving with their hosts. PyVs are generally apathogenic in humans, causing symptoms mainly in immunosuppressed individuals. However, e.g. Merkel cell polyomavirus (species Human polyomavirus 5) is oncogenic like several other mammalian PyVs.

Intra-host molecular evolution is also a feature of some $\mathrm{PyV}$ infections in humans. Mutations in the early region can lead to the expression of a truncated form of the large tumour antigen protein. Rearrangements in the non-coding control region and point mutations in VP1 have been described in two important human PyVs: JCPyV and BKPyV (Helle et al. 2017). In the case of JCPyV, mutations of these loci lead to the development of progressive multifocal leukoencephalopathy. Non-coding control region rearrangements in BKPyV are proposed to play a direct role in the development of PyVassociated nephropathy. Therefore, intra-host viral evolution appears to be an essential component of the disease process (McIlroy et al. 2019).

As discussed already, a recent host switch or a broader host range is usually associated with elevated pathogenicity. This is true for PyVs too: closely related PyVs can be detected in healthy bats of the genus Rhinolophus (Carr et al. 2017), whereas the goose haemorrhagic polyomavirus infects geese, Muscovy ducks and mulards, and the budgerigar fledgling disease virus (species Aves polyomavirus 1) infects birds of diverse families (Johne and Müller 2007).

\section{Circoviruses}

Circoviruses (family Circoviridae) are vertebrate-infecting, single-stranded DNA (ssDNA) viruses with one of the smallest ( 2 kb) virus genomes (Parrish 2011). The circular genome contains two genes (rep and cap) encoding the replication-associated (Rep) and the capsid (Cap) proteins, respectively (Biagini et al. 2011). The first recognised circoviruses, namely porcine circovirus 1 infecting swine and wild boar (Tischer et al. 1982, 1974) and the beak and feather disease virus of parrot species (Pass and Perry 1984) have been known for a long time. Still, the diversity of circoviruses and circular replication-associated protein encoding ssDNA (CRESS DNA) viruses was not revealed until recently. The continuous improvement of molecular methods has facilitated the discovery of numerous novel circo- and CRESS DNA viruses over the past few years (Delwart and Li 2012; Rosario et al. 2017; Shulman and Davidson 2017; Zhao et al. 2019).
Unfortunately, as most of this knowledge originates from metagenomic surveys of environmental samples, the exact host-virus linkage is often hard to decipher. In such cases, different comparative in silico approaches, like cophylogeny analysis of host and virus or a nucleotide composition analysis might help find a solution (Harrach 2000; Kapoor et al. 2010; Kemenesi et al. 2017; Shackelton et al. 2006). The results of some phylogenetic tree reconstructions suggested the potential long-term adaptation of some circovirus groups to birds, mammals, reptiles and fish (Altan et al. 2019; Delwart and Li 2012; Dennis et al. 2018; Fehér et al. 2013).

In relation to circoviruses and their hosts, the research of EVEs and their potential role in host cells has deepened recently. It was revealed that the complete or partial circovirus genome might be integrated into the host genome as an EVE. To date, primarily rep- but also cap-homologues have been detected in different animal genomes using bioinformatics approaches (Aiewsakun and Katzourakis 2015; Aswad and Katzourakis 2012; Belyi et al. 2010; Dennis et al. 2019, 2018; Fehér et al. 2013; Gibbs et al. 2006; Gilbert et al. 2014; Holmes 2011; Horie and Tomonaga 2011; Katzourakis and Gifford 2010; Krupovic and Forterre 2015; Liu et al. 2011). There are various possible functions-e.g. antiviral protection-proposed for different circoviral EVEs depending on the location and type of integration, but the exact impact of these is poorly known (Aswad and Katzourakis 2012; Dennis et al. 2018; Honda and Tomonaga 2016; Horie and Tomonaga 2011; Katzourakis and Gifford 2010; Liu et al. 2011). In the authors' opinion, the quick evolution of these viruses via recombination (Lefeuvre et al. 2009; Martin et al. 2011; Rosario et al. 2012) and the RNA viruslike high mutation rates (Duffy et al. 2008; Firth et al. 2009; Rosario et al. 2012) can facilitate genomic integration, adaptation to the host cell or host switches. This hypothesis is supported by studies of related viruses (Gibbs and Weiller 1999).

By comparative analyses of the Rep-encoding gene superfamily, some authors propose the plant-infecting geminiviruses as the ancestors of both nanoviruses and circoviruses (Londoño et al. 2010; Mankertz et al. 1997; Meehan et al. 1997; Rosario et al. 2012). In the opinion of Gibbs and Weiller (1999), a plant-infecting nanovirus had switched to a herbivorous vertebrate first, and then recombined with a picorna-like virus (supposedly a calicivirus) via a retrotransposable element or a retrovirus. If we dig even deeper, the homologues of the ssDNA virus Rep were described in plasmids of eubacteria and algae, suggesting an evolutionary relationship (Gibbs et al. 2006; Liu et al. 2011; Oshima et al. 2001). In some authors' opinion, the close phylogenetic relatedness of several circoviruses replicating in various host species may be the sign of cross-species transmissions (Delwart and Li 2012; Gibbs et al. 2006; Li et al. 2011; Liu et al. 2011). The common presence of the highly conserved Rep 
and the mechanism of the rolling circle replication (Faurez et al. 2009) are the most obvious evidences for the common ancestry of the ssDNA virus taxa and ssDNA molecules (Martin et al. 2011). Members of the family Circoviridae and related viruses have been existing for 40 to 50 million years. Some authors hypothesise even 100 million years of coevolution with the vertebrates based on EVEs (Belyi et al. 2010; Delwart and Li 2012; Katzourakis and Gifford 2010). By that period-from the middle Cretaceous to the late Eocene epoch - the main vertebrate groups had evolved already (Ravi and Venkatesh 2008). Others estimate the age of bird and mammalian circoviruses to be a mere 500 years, questioning long-term coevolution with the hosts (Firth et al. 2009). The evolutionary route of these viruses is not clear yet, and further research is needed both for circoviruses and their hosts.

\section{Concluding remarks}

As seen from the example of this latest mentioned dispute concerning the appearance of circoviruses, there are a number of unsettled questions in connection with the coevolutionary processes observed in DNA viruses and their hosts. In the paragraphs above, we have listed these major processes. (1) Apparent speciation and coevolution of adenovirus lineages (genera) with the different vertebrate families. Here, host switches to new taxa were marked both with shift in the genome content (codon usage, $\mathrm{A}+\mathrm{T}$ content) and more severe pathology in the non-coevolved hosts. (2) In connection with herpesviruses (HVs) a longer coevolutionary past was supposed, largely synchronous with the more divergent (vertebrate and invertebrate) host lineages. Integrated HV genomes in host chromosomes were demonstrated to provide new data about the genome content of ancient HVs and a new HVs lineage. Moreover, the discovery of a HV core gene homologue in tailed bacteriophages established the phylogenetic relatedness between two seemingly unrelated virus orders (Herpesvirales, Caudovirales) and broadened the perspective for the coevolutionary studies. (3) Concerning NCLDVs, we have discussed that many earlier unrelated virus families with large/giant capsid and genome sizes and even more divergent host range (from protists to vertebrates) can be phylogenetically linked based on a subset of core genes. This phylogenetic reconstruction demonstrated a 'turbulent evolution', which was dominated by gene gain and gene loss via horizontal gene transfer both from other viruses and from host genomes. (4) In connection with polyomaviruses (PyV) the recombination among PyV lineages generating novel virus species was also mentioned, and the importance of the intra-host molecular evolution was discussed in more detail. It was demonstrated that point mutations and rearrangements in non-coding control regions both can critically alter the pathogenic potential, immunogenicity and target organs of related PyVs of a single host species. (5) In the case of circoviruses (or more broadly CRESS DNA viruses), higher mutation rates and rolling circle type replication of their ssDNA, alongside with recombination events and integration into host genomes as well as presumed cross-species transmissions of distant hosts were simultaneously forming the coevolutionary processes.

The above list is extensive, yet not exhaustive. The presented examples cover a large portion of the animal DNA viruses, but many known and yet unknown families with potentially diverse coevolutionary strategies were not covered. One of these could be the recently discovered 'adomaviruses', which are apparently products of rampant gene exchange between adeno-, papilloma- and polyomaviruses and their ancient and more recent (fish) hosts (Welch et al. 2018). As mentioned in the introduction, protein structure based homology searches can reveal such similarities between poorly sequence-conserved proteins and unravel the otherwise hidden evolutionary connections of viruses and their hosts.

Viruses have always been around. Their parasitic lifestyle had an enormous driving effect on the evolution of all organisms, and thus life would not be the same without them. Future research will hopefully shed light on the exact origin and coevolutionary history of all viruses.

Acknowledgements Open access funding provided by MTA Centre for Agricultural Research (MTA ATK). The research of Győző Kaján is supported by the OMA Foundation (Grant 1010̈u6), that of Andor Doszpoly and Márton Z. Vidovszky by the National Research, Development and Innovation Office (K127916 and NN128309, respectively). Győző L. Kaján and Tibor Papp are recipients of the Bolyai Researcher Grant of the Hungarian Academy of Sciences. All authors would like to thank Prof. Dr. Mária Benkő and Prof. Dr. Balázs Harrach in general for establishing and maintaining the Comparative and Molecular Virology Research Group, and specifically for their thought-provoking comments concerning the topic of this paper.

\section{Compliance with Ethical Standards}

Conflict of interest The authors declare that they have no conflicts of interest.

Open Access This article is distributed under the terms of the Creative Commons Attribution 4.0 International License (http://creativeco mmons.org/licenses/by/4.0/), which permits unrestricted use, distribution, and reproduction in any medium, provided you give appropriate credit to the original author(s) and the source, provide a link to the Creative Commons license, and indicate if changes were made.

\section{References}

Aiewsakun P, Katzourakis A (2015) Endogenous viruses: connecting recent and ancient viral evolution. Virology 479-480:26 
Alonso C, Borca M, Dixon L, Revilla Y, Rodriguez F, Escribano JM, ICTV Report Consortium (2018) ICTV virus taxonomy profile: asfarviridae. J Gen Virol 99:613

Altan E, Kubiski SV, Burchell J, Bicknese E, Deng X, Delwart E (2019) The first reptilian circovirus identified infects gut and liver tissues of black-headed pythons. Vet Res 50:35

Andreani J, Khalil JYB, Sevvana M, Benamar S, Di Pinto F, Bitam I, Colson P, Klose T, Rossmann MG, Raoult D, La Scola B (2017) Pacmanvirus, a new giant icosahedral virus at the crossroads between asfarviridae and faustoviruses. J Virol 91:e00212

Armezzani A, Varela M, Spencer TE, Palmarini M, Arnaud F (2014) "Ménage à Trois": the evolutionary interplay between JSRV, enJSRVs and domestic sheep. Viruses 6:4926

Arslan D, Legendre M, Seltzer V, Abergel C, Claverie JM (2011) Distant mimivirus relative with a larger genome highlights the fundamental features of Megaviridae. Proc Natl Acad Sci USA 108:17486

Aswad A, Katzourakis A (2012) Paleovirology and virally derived immunity. Trends Ecol Evol 27:627

Aswad A, Katzourakis A (2017) A novel viral lineage distantly related to herpesviruses discovered within fish genome sequence data. Virus Evol 3:vex016

Bajrai LH, Benamar S, Azhar EI, Robert C, Levasseur A, Raoult D, La Scola B (2016) Kaumoebavirus, a new virus that clusters with faustoviruses and asfarviridae. Viruses 8:278

Baker ML, Jiang W, Rixon FJ, Chiu W (2005) Common ancestry of herpesviruses and tailed DNA bacteriophages. J Virol 79:14967

Ballmann MZ, Harrach B (2016) Detection and partial genetic characterisation of novel avi- and siadenoviruses in racing and fancy pigeons (Columba livia domestica). Acta Vet Hung 64:514

Bândea CI (1983) A new theory on the origin and the nature of viruses. J Theor Biol 105:591

Bell PJ (2006) Sex and the eukaryotic cell cycle is consistent with a viral ancestry for the eukaryotic nucleus. J Theor Biol 243:54

Bell PJ (2009) The viral eukaryogenesis hypothesis: a key role for viruses in the emergence of eukaryotes from a prokaryotic world environment. Ann N Y Acad Sci 1178:91

Belyi VA, Levine AJ, Skalka AM (2010) Sequences from ancestral single-stranded DNA viruses in vertebrate genomes: the parvoviridae and circoviridae are more than 40 to 50 million years old. J Virol 84:12458

Benkő M, Harrach B (1998) A proposal for a new (third) genus within the family Adenoviridae. Arch Virol 143:829

Benkő M, Harrach B (2003) Molecular evolution of adenoviruses. Curr Top Microbiol Immunol 272:3

Benson SD, Bamford JK, Bamford DH, Burnett RM (1999) Viral evolution revealed by bacteriophage PRD1 and human adenovirus coat protein structures. Cell 98:825

Bergstrom CT, McElhany P, Real LA (1999) Transmission bottlenecks as determinants of virulence in rapidly evolving pathogens. Proc Natl Acad Sci USA 96:5095

Biagini P, Bendinelli M, Hino S, Kakkola L, Mankertz A, Niel C, Okamoto H, Raidal S, Teo C, Todd D (2011) Circoviridae. In: King AMQ, Lefkowitz E, Adams MJ, Carstens EB (eds) Virus taxonomy: IXth report of the international committee on taxonomy of viruses. Elsevier, San Diego, pp 343-349

Bill CA, Summers J (2004) Genomic DNA double-strand breaks are targets for hepadnaviral DNA integration. Proc Natl Acad Sci USA 101:11135

Boyer M, Yutin N, Pagnier I, Barrassi L, Fournous G, Espinosa L, Robert C, Azza S, Sun S, Rossmann MG, Suzan-Monti M, La Scola B, Koonin EV, Raoult D (2009) Giant Marseillevirus highlights the role of amoebae as a melting pot in emergence of chimeric microorganisms. Proc Natl Acad Sci USA 106:21848
Broecker F, Moelling K (2019) Evolution of immune systems from viruses and transposable elements. Front Microbiol 10:51

Broecker F, Horton R, Heinrich J, Franz A, Schweiger MR, Lehrach H, Moelling K (2016) The intron-enriched HERV-K(HML-10) family suppresses apoptosis, an indicator of malignant transformation. Mob DNA 7:25

Buck CB, Van Doorslaer K, Peretti A, Geoghegan EM, Tisza MJ, An P, Katz JP, Pipas JM, McBride AA, Camus AC, McDermott AJ, Dill JA, Delwart E, Ng TF, Farkas K, Austin C, Kraberger S, Davison W, Pastrana DV, Varsani A (2016) The ancient evolutionary history of polyomaviruses. PLoS Pathog 12:e1005574

Carr M, Gonzalez G, Sasaki M, Dool SE, Ito K, Ishii A, Hang'ombe BM, Mweene AS, Teeling EC, Hall WW, Orba Y, Sawa H (2017) Identification of the same polyomavirus species in different African horseshoe bat species is indicative of short-range hostswitching events. J Gen Virol 98:2771

Cerutti H, Casas-Mollano JA (2006) On the origin and functions of RNA-mediated silencing: from protists to man. Curr Genet 50:81

Charpentier E, Doudna JA (2013) Biotechnology: rewriting a genome. Nature 495:50

Chuong EB, Elde NC, Feschotte C (2016) Regulatory evolution of innate immunity through co-option of endogenous retroviruses. Science 351:1083

Chuong EB, Elde NC, Feschotte C (2017) Regulatory activities of transposable elements: from conflicts to benefits. Nat Rev Genet 18:71

Claverie JM (2006) Viruses take center stage in cellular evolution. Genome Biol 7:110

Claverie JM, Ogata H, Audic S, Abergel C, Suhre K, Fournier PE (2006) Mimivirus and the emerging concept of "giant" virus. Virus Res 117:133

Claverie JM, Abergel C, Ogata H (2009) Mimivirus. Curr Top Microbiol Immunol 328:89

Colson P, Gimenez G, Boyer M, Fournous G, Raoult D (2011) The giant Cafeteria roenbergensis virus that infects a widespread marine phagocytic protist is a new member of the fourth domain of Life. PLoS ONE 6:e18935

Colson P, de Lamballerie X, Fournous G, Raoult D (2012) Reclassification of giant viruses composing a fourth domain of life in the new order Megavirales. Intervirology 55:321

Colson P, De Lamballerie X, Yutin N, Asgari S, Bigot Y, Bideshi DK, Cheng XW, Federici BA, Van Etten JL, Koonin EV, La Scola B, Raoult D (2013) "Megavirales", a proposed new order for eukaryotic nucleocytoplasmic large DNA viruses. Arch Virol 158:2517

Cornelis G, Funk M, Vernochet C, Leal F, Tarazona OA, Meurice G, Heidmann O, Dupressoir A, Miralles A, Ramirez-Pinilla MP, Heidmann T (2017) An endogenous retroviral envelope syncytin and its cognate receptor identified in the viviparous placental. Proc Natl Acad Sci USA 114:E10991

Crawford-Miksza L, Schnurr DP (1996) Analysis of 15 adenovirus hexon proteins reveals the location and structure of seven hypervariable regions containing serotype-specific residues. J Virol $70: 1836$

Davison AJ (1998) The genome of salmonid herpesvirus 1. J Virol 72:1974

Davison AJ, Davison MD (1995) Identification of structural proteins of channel catfish virus by mass spectrometry. Virology 206:1035

Davison A, Wright K, Harrach B (2000) DNA sequence of frog adenovirus. J Gen Virol 81:2431

Davison AJ, Trus BL, Cheng N, Steven AC, Watson MS, Cunningham C, Le Deuff RM, Renault T (2005) A novel class of herpesvirus with bivalve hosts. J Gen Virol 86:41

Davison AJ, Cunningham C, Sauerbier W, McKinnell RG (2006) Genome sequences of two frog herpesviruses. J Gen Virol $87: 3509$ 
Davison AJ, Eberle R, Ehlers B, Hayward GS, McGeoch DJ, Minson AC, Pellett PE, Roizman B, Studdert MJ, Thiry E (2009) The order Herpesvirales. Arch Virol 154:171

de Koning AP, Gu W, Castoe TA, Batzer MA, Pollock DD (2011) Repetitive elements may comprise over two-thirds of the human genome. PLoS Genet 7:e1002384

Delwart E, Li L (2012) Rapidly expanding genetic diversity and host range of the Circoviridae viral family and other Rep encoding small circular ssDNA genomes. Virus Res 164:114

Dennehy JJ, Friedenberg NA, Holt RD, Turner PE (2006) Viral ecology and the maintenance of novel host use. Am Nat 167:429

Dennis TPW, Flynn PJ, de Souza WM, Singer JB, Moreau CS, Wilson SJ, Gifford RJ (2018) Insights into circovirus host range from the genomic fossil record. J Virol 92:JVI00145

Dennis TPW, de Souza WM, Marsile-Medun S, Singer JB, Wilson SJ, Gifford RJ (2019) The evolution, distribution and diversity of endogenous circoviral elements in vertebrate genomes. Virus Res 262:15

Dewals B, Gillet L, Gerdes T, Taracha EL, Thiry E, Vanderplasschen A (2005) Antibodies against bovine herpesvirus 4 are highly prevalent in wild African buffaloes throughout eastern and southern Africa. Vet Microbiol 110:209

Dewals B, Thirion M, Markine-Goriaynoff N, Gillet L, de Fays K, Minner F, Daix V, Sharp PM, Vanderplasschen A (2006) Evolution of Bovine herpesvirus 4: recombination and transmission between African buffalo and cattle. J Gen Virol 87:1509

Donahue JP, Vetter ML, Mukhtar NA, D'Aquila RT (2008) The HIV-1 Vif PPLP motif is necessary for human APOBEC3G binding and degradation. Virology 377:49

Doszpoly A, Somogyi V, LaPatra SE, Benko M (2011) Partial genome characterization of acipenserid herpesvirus 2: taxonomical proposal for the demarcation of three subfamilies in Alloherpesviridae. Arch Virol 156:2291

Doszpoly A, Wellehan JF, Childress AL, Tarján ZL, Kovács ER, Harrach B, Benkő M (2013) Partial characterization of a new adenovirus lineage discovered in testudinoid turtles. Infect Genet Evol 17:106

Doszpoly A, Harrach B, LaPatra S, Benkő M (2019) Unconventional gene arrangement and content revealed by full genome analysis of the white sturgeon adenovirus, the single member of the genus Ichtadenovirus. Infect Genet Evol 75:103976

Duffy S, Shackelton LA, Holmes EC (2008) Rates of evolutionary change in viruses: patterns and determinants. Nat Rev Genet 9:267

Elena SF, Dopazo J, Flores R, Diener TO, Moya A (1991) Phylogeny of viroids, viroidlike satellite RNAs, and the viroidlike domain of hepatitis delta virus RNA. Proc Natl Acad Sci USA 88:5631

Elena SF, Sanjuán R, Bordería AV, Turner PE (2001) Transmission bottlenecks and the evolution of fitness in rapidly evolving RNA viruses. Infect Genet Evol 1:41

Emerman M, Malik HS (2010) Paleovirology-modern consequences of ancient viruses. PLoS Biol 8:e1000301

Esteso G, Guerra S, Valés-Gómez M, Reyburn HT (2017) Innate immune recognition of double-stranded RNA triggers increased expression of NKG2D ligands after virus infection. J Biol Chem 292:20472

Farkas S, Benkő M, Elő P, Ursu K, Dán A, Ahne W, Harrach B (2002) Genomic and phylogenetic analyses of an adenovirus isolated from a corn snake (Elaphe guttata) imply a common origin with members of the proposed new genus Atadenovirus. J Gen Virol 83:2403

Farley CA, Banfield WG, Kasnic G, Foster WS (1972) Oyster herpestype virus. Science 178:759

Faurez F, Dory D, Grasland B, Jestin A (2009) Replication of porcine circoviruses. Virol J 6:60
Fawcett D (1956) Electron microscope observations on intra-cellular virus-like particles associated with the cells of the Lucke renal adenocarcinoma. J Biophys Biochem Cytol 2:725

Federici BA, Bideshi DK, Tan Y, Spears T, Bigot Y (2009) Ascoviruses: superb manipulators of apoptosis for viral replication and transmission. Curr Top Microbiol Immunol 328:171

Fehér E, Székely C, Lőrincz M, Cech G, Tuboly T, Singh HS, Bányai K, Farkas SL (2013) Integrated circoviral rep-like sequences in the genome of cyprinid fish. Virus Genes 47:374

Filée J (2009) Lateral gene transfer, lineage-specific gene expansion and the evolution of nucleocytoplasmic large DNA viruses. J Invertebr Pathol 101:169

Filée J, Forterre P, Sen-Lin T, Laurent J (2002) Evolution of DNA polymerase families: evidences for multiple gene exchange between cellular and viral proteins. J Mol Evol 54:763

Filée J, Pouget N, Chandler M (2008) Phylogenetic evidence for extensive lateral acquisition of cellular genes by nucleocytoplasmic large DNA viruses. BMC Evol Biol 8:320

Firth C, Charleston MA, Duffy S, Shapiro B, Holmes EC (2009) Insights into the evolutionary history of an emerging livestock pathogen: porcine circovirus 2. J Virol 83:12813

Forterre P (1991) New hypotheses on the origin of prokaryotes, eukaryotes and viruses. In: Trân Thanh Vân J, Mounolou J, Schneider J, McKay C (eds) Frontiers of life. Editions Frontières, Gif sur Yvette, pp 221-233

Gallet R, Fabre F, Thébaud G, Sofonea MT, Sicard A, Blanc S, Michalakis Y (2018) Small bottleneck size in a highly multipartite virus during a complete infection cycle. J Virol 92:e0139

Gibbs MJ, Weiller GF (1999) Evidence that a plant virus switched hosts to infect a vertebrate and then recombined with a vertebrate-infecting virus. Proc Natl Acad Sci USA 96:8022

Gibbs MJ, Smeianov VV, Steele JL, Upcroft P, Efimov BA (2006) Two families of rep-like genes that probably originated by interspecies recombination are represented in viral, plasmid, bacterial, and parasitic protozoan genomes. Mol Biol Evol 23:1097

Gilbert C, Meik JM, Dashevsky D, Card DC, Castoe TA, Schaack S (2014) Endogenous hepadnaviruses, bornaviruses and circoviruses in snakes. Proc Biol Sci 281:20141122

Gilson T, Blanchette P, Ballmann MZ, Papp T, Pénzes JJ, Benkő M, Harrach B, Branton PE (2016) Using the E4orf6-based E3 ubiquitin ligase as a tool to analyze the evolution of adenoviruses. J Virol 90:7350

Gonzalez G, Koyanagi KO, Aoki K, Watanabe H (2015) Interregional coevolution analysis revealing functional and structural interrelatedness between different genomic regions in human mastadenovirus D. J Virol 89:6209

Gorbalenya AE, Pringle FM, Zeddam JL, Luke BT, Cameron CE, Kalmakoff J, Hanzlik TN, Gordon KH, Ward VK (2002) The palm subdomain-based active site is internally permuted in viral RNA-dependent RNA polymerases of an ancient lineage. J Mol Biol 324:47

Gottesman S, Storz G (2011) Bacterial small RNA regulators: versatile roles and rapidly evolving variations. Cold Spring Harb Perspect Biol 3:a003798

Greenbaum BD, Levine AJ, Bhanot G, Rabadan R (2008) Patterns of evolution and host gene mimicry in influenza and other RNA viruses. PLoS Pathog 4:e1000079

Gutiérrez S, Michalakis Y, Blanc S (2012) Virus population bottlenecks during within-host progression and host-to-host transmission. Curr Opin Virol 2:546

Hamilton WD, Axelrod R, Tanese R (1990) Sexual reproduction as an adaptation to resist parasites (a review). Proc Natl Acad Sci USA $87: 3566$

Harrach B (2000) Reptile adenoviruses in cattle? Acta Vet Hung 48:485 
Harrach B (2008) Adenoviruses: general features. In: Mahy B, Regenmortel M (eds) Encyclopedia of virology. Elsevier, Oxford, pp $1-9$

Harrach B (2014) Adenoviruses: general features reference module in biomedical sciences. Elsevier, Amsterdam

Helle F, Brochot E, Handala L, Martin E, Castelain S, Francois C, Duverlie G (2017) Biology of the BKPyV: an update. Viruses 9:327

Hess M, Blöcker H, Brandt P (1997) The complete nucleotide sequence of the egg drop syndrome virus: an intermediate between mastadenoviruses and aviadenoviruses. Virology 238:145

Holmes EC (2011) The evolution of endogenous viral elements. Cell Host Microbe 10:368

Holmes EC (2013) Virus evolution. In: Knipe DM, Howley PM (eds) Fields virology. Wolters Kluwer, Philadelphia, pp 286-313

Hon CC, Lam TY, Shi ZL, Drummond AJ, Yip CW, Zeng F, Lam PY, Leung FC (2008) Evidence of the recombinant origin of a bat severe acute respiratory syndrome (SARS)-like coronavirus and its implications on the direct ancestor of SARS coronavirus. J Virol 82:1819

Honda T, Tomonaga K (2016) Endogenous non-retroviral RNA virus elements evidence a novel type of antiviral immunity. Mob Genet Elements 6:e1165785

Hoppe E, Pauly M, Gillespie TR, Akoua-Koffi C, Hohmann G, Fruth B, Karhemere S, Madinda NF, Mugisha L, Muyembe JJ, Todd A, Petrzelkova KJ, Gray M, Robbins M, Bergl RA, Wittig RM, Zuberbühler K, Boesch C, Schubert G, Leendertz FH, Ehlers B, Calvignac-Spencer S (2015) Multiple cross-species transmission events of human adenoviruses (HAdV) during hominine evolution. Mol Biol Evol 32:2072

Horie M, Tomonaga K (2011) Non-retroviral fossils in vertebrate genomes. Viruses 3:1836

Horner GW, Hunter R, Bartha A, Benkö M (1989) A new subgroup 2 bovine adenovirus proposed as the prototype strain 10. Arch Virol 109:121

Imakawa K, Nakagawa S (2017) The phylogeny of placental evolution through dynamic integrations of retrotransposons. Prog Mol Biol Transl Sci 145:89

Inoue Y, Saga T, Aikawa T, Kumagai M, Shimada A, Kawaguchi Y, Naruse K, Morishita S, Koga A, Takeda H (2017) Complete fusion of a transposon and herpesvirus created the Teratorn mobile element in medaka fish. Nat Commun 8:551

Ismail AM, Cui T, Dommaraju K, Singh G, Dehghan S, Seto J, Shrivastava S, Fedorova NB, Gupta N, Stockwell TB, Madupu R, Heim A, Kajon AE, Romanowski EG, Kowalski RP, Malathi J, Therese KL, Madhavan HN, Zhang Q, Ferreyra LJ, Jones MS, Rajaiya J, Dyer DW, Chodosh J, Seto D (2018a) Genomic analysis of a large set of currently-and historically-important human adenovirus pathogens. Emerg Microbes Infect 7:10

Ismail AM, Lee JS, Lee JY, Singh G, Dyer DW, Seto D, Chodosh J, Rajaiya J (2018b) Adenoviromics: mining the human adenovirus species D genome. Front Microbiol 9:2178

Ito J, Sugimoto R, Nakaoka H, Yamada S, Kimura T, Hayano T, Inoue I (2017) Systematic identification and characterization of regulatory elements derived from human endogenous retroviruses. PLoS Genet 13:e1006883

Iwasaki YW, Siomi MC, Siomi H (2015) PIWI-interacting RNA: its biogenesis and functions. Annu Rev Biochem 84:405

Iyer LM, Koonin EV, Aravind L (2003) Evolutionary connection between the catalytic subunits of DNA-dependent RNA polymerases and eukaryotic RNA-dependent RNA polymerases and the origin of RNA polymerases. BMC Struct Biol 3:1

Jánoska M, Vidovszky M, Molnár V, Liptovszky M, Harrach B, Benko M (2011) Novel adenoviruses and herpesviruses detected in bats. Vet J 189:118
Jenkins GM, Pagel M, Gould EA, de A Zanotto PM, Holmes EC (2001) Evolution of base composition and codon usage bias in the genus Flavivirus. J Mol Evol 52:383

Johne R, Müller H (2007) Polyomaviruses of birds: etiologic agents of inflammatory diseases in a tumor virus family. J Virol 81:11554

Kaján GL, Kajon AE, Pinto AC, Bartha D, Arnberg N (2017) The complete genome sequence of human adenovirus 84 , a highly recombinant new Human mastadenovirus D type with a unique fiber gene. Virus Res 242:79

Kaján GL, Lipiec A, Bartha D, Allard A, Arnberg N (2018) A multigene typing system for human adenoviruses reveals a new genotype in a collection of Swedish clinical isolates. PLoS ONE 13:e0209038

Kapitonov VV, Koonin EV (2015) Evolution of the RAG1-RAG2 locus: both proteins came from the same transposon. Biol Direct 10:20

Kapoor A, Simmonds P, Lipkin WI, Zaidi S, Delwart E (2010) Use of nucleotide composition analysis to infer hosts for three novel picorna-like viruses. J Virol 84:10322

Katzourakis A, Gifford RJ (2010) Endogenous viral elements in animal genomes. PLoS Genet 6:e1001191

Katzourakis A, Tristem M, Pybus OG, Gifford RJ (2007) Discovery and analysis of the first endogenous lentivirus. Proc Natl Acad Sci USA 104:6261

Kelley G, Waltzek T, McDowell T, Yun S, LaPatra S, Hedrick RP (2005) Genetic relationships among herpes-like viruses isolated from sturgeon. J Aqua Anim Health 17:297

Kemenesi G, Kurucz K, Zana B, Tu VT, Görföl T, Estók P, Földes F, Sztancsik K, Urbán P, Fehér E, Jakab F (2017) Highly divergent cyclo-like virus in a great roundleaf bat (Hipposideros armiger) in Vietnam. Arch Virol 162:2403

Khatchikian D, Orlich M, Rott R (1989) Increased viral pathogenicity after insertion of a $28 \mathrm{~S}$ ribosomal RNA sequence into the haemagglutinin gene of an influenza virus. Nature 340:156

Kobayashi I (2001) Behavior of restriction-modification systems as selfish mobile elements and their impact on genome evolution. Nucleic Acids Res 29:3742

Kohl C, Vidovszky MZ, Mühldorfer K, Dabrowski PW, Radonić A, Nitsche A, Wibbelt G, Kurth A, Harrach B (2012) Genome analysis of bat adenovirus 2: indications of interspecies transmission. J Virol 86:1888

Koonin EV (2009) Evolution of genome architecture. Int J Biochem Cell Biol 41:298

Koonin EV, Makarova KS (2017) Mobile genetic elements and evolution of CRISPR-Cas systems: all the way there and back. Genome Biol Evol 9:2812

Koonin EV, Yutin N (2010) Origin and evolution of eukaryotic large nucleo-cytoplasmic DNA viruses. Intervirology 53:284

Koonin EV, Yutin N (2018) Multiple evolutionary origins of giant viruses. F1000Research 7:1840

Koonin EV, Yutin N (2019) Evolution of the large nucleocytoplasmic DNA viruses of eukaryotes and convergent origins of viral gigantism. Adv Virus Res 103:167

Kovács ER, Benko M (2011) Complete sequence of raptor adenovirus 1 confirms the characteristic genome organization of siadenoviruses. Infect Genet Evol 11:1058

Kovács G, LaPatra S, D'Halluin J, Benko M (2003) Phylogenetic analysis of the hexon and protease genes of a fish adenovirus isolated from white sturgeon (Acipenser transmontanus) supports the proposal for a new adenovirus genus. Virus Res 98:27

Kovács ER, Jánoska M, Dán A, Harrach B, Benko M (2010) Recognition and partial genome characterization by non-specific DNA amplification and PCR of a new siadenovirus species in a sample originating from Parus major, a great tit. J Virol Methods 163:262 
Krupovic M, Forterre P (2015) Single-stranded DNA viruses employ a variety of mechanisms for integration into host genomes. Ann N Y Acad Sci 1341:41

Krupovic M, Koonin EV (2015) Polintons: a hotbed of eukaryotic virus, transposon and plasmid evolution. Nat Rev Microbiol 13:105

Krupovic M, Koonin EV (2017) Multiple origins of viral capsid proteins from cellular ancestors. Proc Natl Acad Sci USA 114:E2401

La Scola B, Audic S, Robert C, Jungang L, de Lamballerie X, Drancourt M, Birtles R, Claverie JM, Raoult D (2003) A giant virus in amoebae. Science 299:2033

Lee SY, Kim JH, Park YM, Shin OS, Kim H, Choi HG, Song JW (2014) A novel adenovirus in Chinstrap penguins (Pygoscelis antarctica) in Antarctica. Viruses 6:2052

Lefeuvre P, Lett JM, Varsani A, Martin DP (2009) Widely conserved recombination patterns among single-stranded DNA viruses. J Virol 83:2697

Lehmkuhl HD, Hobbs LA, Woods LW (2001) Characterization of a new adenovirus isolated from black-tailed deer in California. Arch Virol 146:1187

Levy DE, Marié IJ, Durbin JE (2011) Induction and function of type I and III interferon in response to viral infection. Curr Opin Virol 1:476

Li L, Shan T, Soji OB, Alam MM, Kunz TH, Zaidi SZ, Delwart E (2011) Possible cross-species transmission of circoviruses and cycloviruses among farm animals. J Gen Virol 92:768

Liu H, Fu Y, Li B, Yu X, Xie J, Cheng J, Ghabrial SA, Li G, Yi X, Jiang D (2011) Widespread horizontal gene transfer from circular single-stranded DNA viruses to eukaryotic genomes. BMC Evol Biol 11:276

Londoño A, Riego-Ruiz L, Argüello-Astorga GR (2010) DNA-binding specificity determinants of replication proteins encoded by eukaryotic ssDNA viruses are adjacent to widely separated RCR conserved motifs. Arch Virol 155:1033

Lucía-Sanz A, Manrubia S (2017) Multipartite viruses: adaptive trick or evolutionary treat? NPJ Syst Biol Appl 3:34

Malim MH, Emerman M (2001) HIV-1 sequence variation: drift, shift, and attenuation. Cell 104:469

Mankertz A, Persson F, Mankertz J, Blaess G, Buhk HJ (1997) Mapping and characterization of the origin of DNA replication of porcine circovirus. J Virol 71:2562

Martin DP, Biagini P, Lefeuvre P, Golden M, Roumagnac P, Varsani A (2011) Recombination in eukaryotic single stranded DNA viruses. Viruses 3:1699

McCrone JT, Lauring AS (2018) Genetic bottlenecks in intraspecies virus transmission. Curr Opin Virol 28:20

McGeoch DJ, Gatherer D (2005) Integrating reptilian herpesviruses into the family herpesviridae. J Virol 79:725

McGeoch DJ, Cook S, Dolan A, Jamieson FE, Telford EA (1995) Molecular phylogeny and evolutionary timescale for the family of mammalian herpesviruses. J Mol Biol 247:443

McGeoch DJ, Dolan A, Ralph AC (2000) Toward a comprehensive phylogeny for mammalian and avian herpesviruses. J Virol 74:10401

McGeoch DJ, Rixon FJ, Davison AJ (2006) Topics in herpesvirus genomics and evolution. Virus Res 117:90

McIlroy D, Halary F, Bressollette-Bodin C (2019) Intra-patient viral evolution in polyomavirus-related diseases. Philos Trans R Soc Lond B Biol Sci 374:20180301

McLaughlin RN, Malik HS (2017) Genetic conflicts: the usual suspects and beyond. J Exp Biol 220:6

Meehan BM, Creelan JL, McNulty MS, Todd D (1997) Sequence of porcine circovirus DNA: affinities with plant circoviruses. J Gen Virol 78(Pt 1):221

Moelling K, Broecker F (2019) Viruses and evolution-viruses first? A personal perspective. Front Microbiol 10:523
Moelling K, Abels S, Jendis J, Matskevich A, Heinrich J (2006) Silencing of HIV by hairpin-loop-structured DNA oligonucleotide. FEBS Lett 580:3545

Moelling K, Broecker F, Russo G, Sunagawa S (2017) RNase H as gene modifier, driver of evolution and antiviral defense. Front Microbiol 8:1745

Moens U, Calvignac-Spencer S, Lauber C, Ramqvist T, Feltkamp MCW, Daugherty MD, Verschoor EJ, Ehlers B, ICTV Report Consortium (2017a) ICTV virus taxonomy profile: polyomaviridae. J Gen Virol 98:1159

Moens U, Krumbholz A, Ehlers B, Zell R, Johne R, Calvignac-Spencer S, Lauber C (2017b) Biology, evolution, and medical importance of polyomaviruses: an update. Infect Genet Evol 54:18

Moreira D, Brochier-Armanet C (2008) Giant viruses, giant chimeras: the multiple evolutionary histories of Mimivirus genes. BMC Evol Biol 8:12

Moreira D, López-García P (2005) Comment on "The 1.2-megabase genome sequence of Mimivirus". Science 308:1114

Moreira D, López-García P (2009) Ten reasons to exclude viruses from the tree of life. Nat Rev Microbiol 7:306

Morissette G, Flamand L (2010) Herpesviruses and chromosomal integration. J Virol 84:12100

Nagy M, Nagy E, Tuboly T (2002) Sequence analysis of porcine adenovirus serotype 5 fibre gene: evidence for recombination. Virus Genes 24:181

Nasir A, Caetano-Anollés G (2015) A phylogenomic data-driven exploration of viral origins and evolution. Sci Adv 1:e1500527

Nasir A, Caetano-Anollés G (2017) Identification of capsid/coat related protein folds and their utility for virus classification. Front Microbiol 8:380

Nora T, Charpentier C, Tenaillon O, Hoede C, Clavel F, Hance AJ (2007) Contribution of recombination to the evolution of human immunodeficiency viruses expressing resistance to antiretroviral treatment. J Virol 81:7620

Novella IS, Elena SF, Moya A, Domingo E, Holland JJ (1995) Size of genetic bottlenecks leading to virus fitness loss is determined by mean initial population fitness. J Virol 69:2869

Oliveira GP, Rodrigues RAL, Lima MT, Drumond BP, Abrahão JS (2017) Poxvirus host range genes and virus-host spectrum: a critical review. Viruses 9:331

Oshima K, Kakizawa S, Nishigawa H, Kuboyama T, Miyata S, Ugaki M, Namba S (2001) A plasmid of phytoplasma encodes a unique replication protein having both plasmid- and virus-like domains: clue to viral ancestry or result of virus/plasmid recombination? Virology 285:270

Pantó L, Podgorski II, Jánoska M, Márkó O, Harrach B (2015) Taxonomy proposal for old world monkey adenoviruses: characterisation of several non-human, non-ape primate adenovirus lineages. Arch Virol 160:3165

Papp T, Fledelius B, Schmidt V, Kaján GL, Marschang RE (2009) PCR-sequence characterization of new adenoviruses found in reptiles and the first successful isolation of a lizard adenovirus. Vet Microbiol 134:233

Parrish C (2011) Circoviridae. In: MacLachlan N, Dubovi E (eds) Fenner's veterinary virology. Academic Press, London, pp 237-242

Pass DA, Perry RA (1984) The pathology of psittacine beak and feather disease. Aust Vet J 61:69

Peck KM, Lauring AS (2018) Complexities of viral mutation rates. J Virol 92:e01031

Pellett PE, Davison AJ, Eberle R, Ehlers B, Hayward GS, Lacoste V, Minson AC, Nicholas J, Roizman B, Studdert MJ, Wang F (2011) Family Herpesviridae. In: King AMQ, Lefkowitz E, Adams MJ, Carstens EB (eds) Virus taxonomy, IXth report of the International Committee on Taxonomy of viruses. Elsevier, San Diego, pp 99-123 
Peretti A, FitzGerald PC, Bliskovsky V, Pastrana DV, Buck CB (2015) Genome sequence of a fish-associated polyomavirus, Black Sea Bass (Centropristis striata) Polyomavirus 1. Genome Announc 3:e01476

Piégu B, Asgari S, Bideshi D, Federici BA, Bigot Y (2015) Evolutionary relationships of iridoviruses and divergence of ascoviruses from invertebrate iridoviruses in the superfamily Megavirales. Mol Phylogenet Evol 84:44

Podgorski II, Pantó L, Papp T, Harrach B, Benkö M (2016) Genome analysis of four old world monkey adenoviruses supports the proposed species classification of primate adenoviruses and reveals signs of possible homologous recombination. J Gen Virol 97:1604

Podgorski II, Pantó L, Földes K, de Winter I, Jánoska M, Sós E, Chenet B, Harrach B, Benkő M (2018) Adenoviruses of the most ancient primate lineages support the theory on virus-host co-evolution. Acta Vet Hung 66:474

Prugnolle F, Manica A, Charpentier M, Guégan JF, Guernier V, Balloux F (2005) Pathogen-driven selection and worldwide HLA class I diversity. Curr Biol 15:1022

Purkayastha A, Ditty SE, Su J, McGraw J, Hadfield TL, Tibbetts C, Seto D (2005) Genomic and bioinformatics analysis of HAdV-4, a human adenovirus causing acute respiratory disease: implications for gene therapy and vaccine vector development. J Virol 79:2559

Raoult D, Audic S, Robert C, Abergel C, Renesto P, Ogata H, La Scola B, Suzan M, Claverie JM (2004) The 1.2-megabase genome sequence of Mimivirus. Science 306:1344

Ravi V, Venkatesh B (2008) Rapidly evolving fish genomes and teleost diversity. Curr Opin Genet Dev 18:544

Rebell G, Rywlin A, Haines H (1975) A herpesvirus-type agent associated with skin lesions of green sea turtles in aquaculture. Am J Vet Res 36:1221

Robinson CM, Singh G, Lee JY, Dehghan S, Rajaiya J, Liu EB, Yousuf MA, Betensky RA, Jones MS, Dyer DW, Seto D, Chodosh J (2013) Molecular evolution of human adenoviruses. Sci Rep 3:1812

Rosario K, Duffy S, Breitbart M (2012) A field guide to eukaryotic circular single-stranded DNA viruses: insights gained from metagenomics. Arch Virol 157:1851

Rosario K, Breitbart M, Harrach B, Segalés J, Delwart E, Biagini P, Varsani A (2017) Revisiting the taxonomy of the family Circoviridae: establishment of the genus Cyclovirus and removal of the genus Gyrovirus. Arch Virol 162:1447

Rossiter PB, Gumm ID, Stagg DA, Conrad PA, Mukolwe S, Davies FG, White H (1989) Isolation of bovine herpesvirus-3 from African buffaloes (Syncerus caffer). Res Vet Sci 46:337

Roy S, Vandenberghe LH, Kryazhimskiy S, Grant R, Calcedo R, Yuan X, Keough M, Sandhu A, Wang Q, Medina-Jaszek CA, Plotkin JB, Wilson JM (2009) Isolation and characterization of adenoviruses persistently shed from the gastrointestinal tract of non-human primates. PLoS Pathog 5:e1000503

Russell JN, Marsh AK, Willer DO, Ambagala AP, Dzamba M, Chan JK, Pilon R, Fournier J, Brudno M, Antony JM, Sandstrom P, Evans BJ, MacDonald KS (2016) A novel strain of cynomolgus macaque cytomegalovirus: implications for host-virus coevolution. BMC Genom 17:277

Sanchez-Mazas A, Lemaître JF, Currat M (2012) Distinct evolutionary strategies of human leucocyte antigen loci in pathogen-rich environments. Philos Trans R Soc Lond B Biol Sci 367:830

Sanjuán R, Domingo-Calap P (2016) Mechanisms of viral mutation. Cell Mol Life Sci 73:4433

Savin KW, Cocks BG, Wong F, Sawbridge T, Cogan N, Savage D, Warner S (2010) A neurotropic herpesvirus infecting the gastropod, abalone, shares ancestry with oyster herpesvirus and a herpesvirus associated with the amphioxus genome. Virol J 7:308

Schachner A, Matos M, Grafl B, Hess M (2018) Fowl adenovirusinduced diseases and strategies for their control-a review on the current global situation. Avian Pathol 47:111

Shackelton LA, Holmes EC (2004) The evolution of large DNA viruses: combining genomic information of viruses and their hosts. Trends Microbiol 12:458

Shackelton LA, Parrish CR, Holmes EC (2006) Evolutionary basis of codon usage and nucleotide composition bias in vertebrate DNA viruses. J Mol Evol 62:551

Sheehy AM, Gaddis NC, Choi JD, Malim MH (2002) Isolation of a human gene that inhibits HIV-1 infection and is suppressed by the viral Vif protein. Nature 418:646

Shulman LM, Davidson I (2017) Viruses with circular single-stranded DNA genomes are everywhere. Annu Rev Virol 4:159

Tarlinton RE, Meers J, Young PR (2006) Retroviral invasion of the koala genome. Nature 442:79

tenOever BR (2016) The evolution of antiviral defense systems. Cell Host Microbe 19:142

Tischer I, Rasch R, Tochtermann G (1974) Characterization of papovavirus-and picornavirus-like particles in permanent pig kidney cell lines. Zentralbl Bakteriol Orig A 226:153

Tischer I, Gelderblom H, Vettermann W, Koch MA (1982) A very small porcine virus with circular single-stranded DNA. Nature 295:64

Todd WJ, Storz J (1983) Morphogenesis of a cytomegalovirus from an American bison affected with malignant catarrhal fever. J Gen Virol 64:1025

Ursu K, Harrach B, Matiz K, Benko M (2004) DNA sequencing and analysis of the right-hand part of the genome of the unique bovine adenovirus type 10. J Gen Virol 85:593

Vidovszky M, Kohl C, Boldogh S, Görföl T, Wibbelt G, Kurth A, Harrach B (2015) Random sampling of the Central European bat fauna reveals the existence of numerous hitherto unknown adenoviruses. Acta Vet Hung 63:508

Villarreal LP (2009) The source of self: genetic parasites and the origin of adaptive immunity. Ann N Y Acad Sci 1178:194

Villarreal LP, Witzany G (2010) Viruses are essential agents within the roots and stem of the tree of life. J Theor Biol 262:698

Voskarides K, Christaki E, Nikolopoulos GK (2018) Influenza virushost co-evolution. A predator-prey relationship? Front Immunol 9:2017

Walsh MP, Chintakuntlawar A, Robinson CM, Madisch I, Harrach B, Hudson NR, Schnurr D, Heim A, Chodosh J, Seto D, Jones MS (2009) Evidence of molecular evolution driven by recombination events influencing tropism in a novel human adenovirus that causes epidemic keratoconjunctivitis. PLoS ONE 4:e5635

Waltzek TB, Kelley GO, Alfaro ME, Kurobe T, Davison AJ, Hedrick RP (2009) Phylogenetic relationships in the family Alloherpesviridae. Dis Aquat Organ 84:179

Wang X, Kim Y, Ma Q, Hong SH, Pokusaeva K, Sturino JM, Wood TK (2010) Cryptic prophages help bacteria cope with adverse environments. Nat Commun 1:147

Weaver SC (2006) Evolutionary influences in arboviral disease. Curr Top Microbiol Immunol 299:285

Welch NL, Yutin N, Dill JA, Camus AC, Pang Y-YS, Schiller JT, An P, Cantalupo PG, Pipas JM, Delwart E, Koda S, Subramaniam K, Waltzek TB, Bian C, Shi Q, Ruan Z, Koonin EV, Buck CB, $\mathrm{Ng}$ TFF (2018) Adomaviruses: an emerging virus family provides insights into DNA virus evolution. bioRxiv. https://doi. org/10.1101/341131

Wellehan J, Johnson A, Harrach B, Benkő M, Pessier A, Johnson C, Garner M, Childress A, Jacobson E (2004) Detection and analysis of six lizard adenoviruses by consensus primer PCR provides 
further evidence of a reptilian origin for the atadenoviruses. J Virol 78:13366

Wevers D, Metzger S, Babweteera F, Bieberbach M, Boesch C, Cameron K, Couacy-Hymann E, Cranfield M, Gray M, Harris LA, Head J, Jeffery K, Knauf S, Lankester F, Leendertz SA, Lonsdorf E, Mugisha L, Nitsche A, Reed P, Robbins M, Travis DA, Zommers Z, Leendertz FH, Ehlers B (2011) Novel adenoviruses in wild primates: a high level of genetic diversity and evidence of zoonotic transmissions. J Virol 85:10774

Wolf K, Darlington RW (1971) Channel catfish virus: a new herpesvirus of ictalurid fish. J Virol 8:525

Woods LW, Swift PK, Barr BC, Horzinek MC, Nordhausen RW, Stillian MH, Patton JF, Oliver MN, Jones KR, MacLachlan NJ (1996) Systemic adenovirus infection associated with high mortality in mule deer (Odocoileus hemionus) in California. Vet Pathol 33:125
Young SM, Samulski RJ (2001) Adeno-associated virus (AAV) sitespecific recombination does not require a Rep-dependent origin of replication within the AAV terminal repeat. Proc Natl Acad Sci USA 98:13525

Zadravec M, Slavec B, Krapez U, Kaján GL, Racnik J, Juntes P, JursicCizerl R, Benkö M, Zorman Rojs O (2011) Inclusion body hepatitis associated with fowl adenovirus type $8 \mathrm{~b}$ in broiler flock in Slovenia-a case report. Slov Vet Res 48:107

Zhao L, Rosario K, Breitbart M, Duffy S (2019) Eukaryotic circular rep-encoding single-stranded DNA (CRESS DNA) viruses: ubiquitous viruses with small genomes and a diverse host range. Adv Virus Res 103:71

Zwart MP, Elena SF (2015) Matters of size: genetic bottlenecks in virus infection and their potential impact on evolution. Annu Rev Virol 2:161 